\title{
ANAEROBIC DIGESTION AS CENTRE OF DAIRY LIVESTOCK AND AGRICULTURE INTEGRATION: BASIS FOR MEDIUM-SCALE CDM PROJECTS DEVELOPMENT
}

\author{
F. A. S. Fiorelli ${ }^{\mathrm{a}}$, ABSTRACT \\ G. O. Diaz ${ }^{\mathbf{b}}$, \\ Dairy producers should improve their activity with modern production \\ techniques/technologies to meet the requirements of a stricter consumer \\ market. In this sense, crop and livestock systems integration represents an

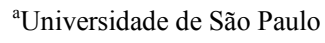 \\ Escola Politécnica \\ Departamento de Engenharia Mecânica \\ Av. Prof. Mello Moraes, 2231 \\ interesting alternative for using the dairy farm available resources. This \\ paper analyses the use of anaerobic digestion as basis for supplying energy, \\ fertilizers and feed needs of a farming unit, by means of digestion products \\ usage: biogas, which can be used in energy conversion systems to provide \\ the required energy for processing/conservation equipment for milk and \\ other farming products; and effluent, that can be used as a replacement for \\ chemical fertilizers and for aquatic plants/fish feeding. Fossil fuels \\ replacement by biogas can be classified as a Clean Development \\ Mechanism (CDM) project, and economic resources obtained by carbon \\ credits commercialisation may support the required production \\ modernisation. The paper analyses the anaerobic digestion process, \\ evaluating biogas in medium-scale dairy farms, as well as the quantification \\ of carbon credits generated by introducing proper manure and culture \\ remains management. \\ Bustamante y Rivero \\ Arequipa, Peru \\ Keywords: rural development, medium-scale dairy farm, biogas and \\ effluent utilisation.
}

\section{NOMENCLATURE}

CDM clean development mechanism

GHG green house gases

IPCC intergovernmental panel on climate change

IC investment cost, R\$

LCS lifecycle savings, R\$

MC maintenance cost, R\$

OC operational cost, $\mathrm{R} \$$

PV present value

TC total cost, R\$

UN United Nations

\section{Subscripts \\ equiv equivalent \\ VS volatile solids}

\section{INTRODUCTION}

Nowadays, concerns about energy availability, processes optimisation and stricter environmental regulations are motivating researches on energy conversion/ generation systems based on renewable energy as a replacement for petroleum and coal. Depending on geographical aspects, the most promising renewable sources are solar, aeolic and geothermal energy, as well as biomass.

Biomass was the main source of energy until the early $20^{\text {th }}$ century, when petroleum and coal took its place. By the 1990s, environmental concerns led to retaking researches on conversion systems based on this energy resource, mainly studying thermochemical (direct combustion and gasification) and biological processes (anaerobic digestion). Such researches allowed the development of equipment capable of improving the energy potential of this lowdensity source and the growth of its usage.

The largest biomass resources are in rural areas and agroindustries, where the amount of organic waste (harvest waste, animal manure, agroindustrial effluents and others) is significant and might justify the implementation of decentralised small-scale energy conversion systems for meeting local energy requirements and/or for integration to the energy grid.

Dairy farms present some characteristics that make them very interesting for this kind of implementation. On one hand, there is a great amount of organic waste (mainly the manure), for which a proper final destination is required and, on the other hand, a significant energy demand for proper handling, treatment and conservation of the milk, mainly in farms that are distant from dairy collection centres.

Due to the growing demand for dairy products with extended expiration dates, maintaining their organoleptic, nutritive and quality characteristics, several governmental regulations require, among other procedures, in-situ milk chilling.

The Brazilian dairy sector is characterised by a large number of producers, presenting low productiveness and product quality. In order to change this scenario, the Brazilian government implemented the National Program of Milk Quality 
Improvement (PNQL) requiring chilling in order to increase the sector competitiveness and to promote its modernisation (Nero et al., 2005). In fact, the implementation of a milk chilling system is necessary for the producer to assure his presence in a very competitive market. Nevertheless, the main drawbacks to a wider use of those systems, besides cultural aspects, are access to financial resources and energy availability.

The implementation of a Kyoto Protocol Clean Development Mechanism (CDM) project for proper manure management in anaerobic digesters, in order to reduce greenhouse gases (GHG) emissions may be a solution for these drawbacks. This kind of project generates financial resources by carbon credit commercialisation, as well as a low-cost energy source (biogas produced by digestion process) and a natural replacement for chemical fertilizers (effluent). The Integrated Farming System (IFS) resulting from project implementation is an interesting way of reducing farming activity and investment costs (Chan, 1985), particularly for small and mediumscale farms, as well as to minimize the environmental impact from human activity.

\section{MILK CHILLING}

Milk offers conditions for microorganism proliferation in a short time span. Proper procedures for extraction, handling, conservation and transport are important in order to inhibit such proliferation or to destroy microorganisms. Concerning conservation, either physical, chemical or biological methods can be employed, and must be applied as soon after extraction as possible in order to take advantage of the action of some natural inhibitors present in the milk.

In order to foster milk production specialization in Brazil, producers get economic incentives for delivering cold milk to collecting centres: 5\% additional in milk price, and a reduction of $50 \%$ in transport fees (Sant'anna et al., 2003).

Nevertheless, considering that investment costs are a direct relation to the cooling tank size, as well as investment risks, such incentives may be insufficient for a single small producer to implement an in-situ milk cooling system. A larger collective system implementation would be a more suitable solution in a short-term scenario, and it would also lead to the establishment of a producer cooperative in the future.

\section{ANAEROBIC DIGESTION}

Anaerobic digestion is a two-stage process to decompose organic residues (volatile solids) in the absence of oxygen, producing biogas and effluent as products. At the first stage, volatile solids are converted into oleic acids by anaerobic bacteria known as acid formers. At the second stage, acids are converted into biogas by other bacteria known as methane formers.

Biogas is basically a mixture of $\mathrm{CH}_{4}$ and $\mathrm{CO}_{2}$, as well as other gases in small amounts. Its heating value and density respectively affect the operation of energy-converting equipment and compressionstorage auxiliary systems. Such parameters are a function of biogas composition (Table 1), which is basically dependant on organic residues quality and digestion process characteristics. Typical values of lower heating value for a biogas with 50 to $80 \%$ of methane ranges from 17.82 to $28.44 \mathrm{MJ} / \mathrm{m}^{3}$ (Bayer et al., 2000).

Table 2 presents the typical consumption of several biogas usages. The most common of such usages in farms are direct combustion for cooking and lighting and internal-combustion engines operation.

Effluent, the other product resulting from anaerobic digestion, can be used as fertilizer for several types of cultures, since it is composed of organic matter with low carbon and high phosphorus content, and its advanced decomposition state facilitates nutrient absorption by the soil.

Table 1. Biogas typical composition (Jensen \& Jensen, 2000)

\begin{tabular}{cc}
\hline Component & Amount \\
\hline $\mathrm{CH}_{4}, \%(\mathrm{vol})$ & $55-70$ \\
$\mathrm{CO}_{2}, \%(\mathrm{vol})$ & $30-45$ \\
$\mathrm{~N}_{2}, \%(\mathrm{vol})$ & $0-2$ \\
$\mathrm{H}_{2} \mathrm{~S}, \mathrm{ppm}$ & $\sim 500$ \\
$\mathrm{NH}_{3}, \mathrm{ppm}$ & $\sim 100$ \\
\hline
\end{tabular}

Table 2. Biogas consumption (Werner et al., 1989; Massoti, 2003)

\begin{tabular}{cc}
\hline Usage & Consumption \\
\hline Cooking (one person) & $0.24-0.30 \mathrm{~m}^{3} /$ day \\
Lighting (40W lamp) & $0.28 \mathrm{~m}^{3} / \mathrm{h}$ \\
Lighting (gas lamp) & $0.12 \mathrm{~m}^{3} / \mathrm{h}$ \\
Electricity generation & $0.62 \mathrm{~m}^{3} / \mathrm{kWh}$ \\
Absorption fridge & $2.50 \mathrm{~m}^{3} / \mathrm{day}$ \\
Gas-driven engines & $0.42\left(\mathrm{~m}^{3} / \mathrm{h}\right) / \mathrm{HP}$ \\
\hline
\end{tabular}

\section{FARM BIOGAS-BASED ENERGY GENERA- TION SYSTEMS}

A biogas-based energy generation system is typically composed by a biodigester, a gas-handling unit and the energy-converting equipment. Removal of $\mathrm{CO}_{2}$ content raises biogas heating value and facilitates it compression (Walsh, 1988; Jensen \& Jensen, 2000), and $\mathrm{H}_{2} \mathrm{~S}$ removal avoids early deterioration of the converting machinery, since the gas, when combined with water, forms sulphur acid, which is highly corrosive. 
It is a common practice in dairy farms that are far-off the electricity grid, to use combustion enginedriven generators, based either in Otto or Diesel engines, to generate the energy required for milk extraction and cooling, lighting, cleaning, and other equipment/systems.

Liquid-fuelled internal combustion engines can be easily adapted for partial or total use of biogas as replacement for fossil fuels (gasoline, kerosene, diesel). Considering a stationary engine, it is basically necessary to add a biogas mixer, since the digestor itself acts as a storage tank, delivering the biogas at pressure levels suitable for a proper engine operation.

\section{THE GREENHOUSE EFFECT AND AGRICUL- TURE}

Human activities have always impacted the environment, but after the Industrial Revolution in the $18^{\text {th }}$ century this impact became global and exponentially increased, reaching levels that are severely damaging the Earth, as pointed out by the recent Intergovernmental Panel on Climate Change (IPCC) $4^{\text {th }}$ report on climate change (IPCC, 2007).

Such activities produce greenhouse effect gases (GHG), affecting the atmosphere composition and increasing the global average temperature (IPCC estimates that this increase ranges from 1.8 to $4.0^{\circ} \mathrm{C}$ by the year 2100). Among the GHG, carbon dioxide $\left(\mathrm{CO}_{2}\right)$, nitrous oxides $\left(\mathrm{NO}_{\mathrm{X}}\right)$, methane $\left(\mathrm{CH}_{4}\right)$ and hydrofluorocarbons (HFC) must be pointed out, deriving respectively from fossil fuels, biomass burning and agricultural activities, refrigeration and sprays (Liborio, 2005).

The IPCC was created by the United Nations (UN) in 1988 to investigate and analyse the effect of GHG emissions. Another UN initiative was the Kyoto Protocol, an international agreement imposing reduction targets for developed countries GHG emissions by the year 2012, and requiring developing countries to commit to a clean and sustainable development.

The Kyoto Protocol also established flexible mechanisms in order to help developed economies to meet their GHG targets by purchasing GHG emission reductions (the Certified Emission Reductions - CER, also called "carbon credits") from elsewhere, either from financial exchanges or from projects that reduce emissions in developing economies under the Clean Development Mechanism (CDM), such as the implementation of IFS systems based on biodigesters and biogas-generated electricity. The CDM Executive Board is responsible for CER emission and control.

Several developing countries are adopting measures to take a significant part in the "carbon market" in order to get investments for their own development. The Brazilian government, for example, estimates that carbon credits demand will reach US\$ 30 billion/year by 2012, with a Brazilian market share of at least 10\% (Brunacci, 2005).

There were $244 \mathrm{CDM}$ projects in course in 2005. The main beneficiary countries are Brazil, India and China, with respectively $74(30 \%), 54$ $(22 \%)$ e $14(8 \%)$ projects (Guimarães, 2005). Most of these projects are related to energy generation or waste management/treatment. Several industries (steel producers, paper manufacturers, agroindustries, reforesting companies and others) are already taking advantage of the carbon credit market.

Anaerobic digestion usage in dairy farms for biogas recovery, and its possible use as an energy source, has the basic characteristics of a CDM project. According to the first Brazilian inventory on cattle methane emissions, by the year 1994, methane emissions were 9.8 million tons $(9.4$ million from enteric fermentation and 0.4 million from manure management systems). By that year, the Brazilian flock was of about 158 million animals, and $13 \%$ of that was dairy cattle (Lima et al., 2006).

CDM projects typically have high implementation costs, particularly at the initial stages, because the learning process and the methodology consolidation, and this is a more serious issue for small-size projects. In order to overcome this drawback, small dairy farms may look for partnerships with investors interested in supporting this kind of CDM projects.

For instance, there is an Irish company that has already installed up to 500 biodigesters in small farms in Brazil and intends to set up another thousand in a short term (Souza, 2005). The farmer is responsible for the proper operation of the equipment and can use the generated biogas and effluent; the income resulting from carbon credits commercialisation is shared between the company $(90 \%)$ and the farmer $(10 \%)$.

\section{FARM POTENTIAL EVALUATION}

In order to evaluate the potential for implementation of a small/medium size CDM project, Diaz (2006) analysed a dairy farm with a 50cow herd that already uses or intends to use in-situ milk chilling equipment in order to meet the Brazilian quality regulations as well as to improve farm productivity, competitiveness and profitability.

It is assumed that the project is related to a biodigester-based CDM project implemented under a farmer-investor partnership as previously mentioned (Souza, 2005). Two possible scenarios are considered:

- one farm that already has electricity-based chilling equipment and intends to replace the purchased electricity by local generation using the biogas provided by the CDM project;

- one farm that does not have chilling equipment yet. 
For both scenarios, the GHG emission reduction and CDM carbon credit generation are evaluated, as well as the best configuration for the milk chilling system, considering the thermo-economic aspects involved and the Brazilian perspective.

\section{GHG EMISSIONS AND CARBON CREDITS GENERATION}

As mentioned before, the analysis is based on a 50-dairy-cow herd. The methodology presented in the IPCC Guidelines for national greenhouse gas inventories (IPCC, 1996) was employed, assuming for Brazil, particularly for its south-eastern region, characteristics similar to those in North America and Western Europe. It was also adopted the parameters presented in Table 3.

Table 3. Parameters adopted for GHG emission evaluation (IPCC, 1996)

\begin{tabular}{cc}
\hline Parameter & Value \\
\hline Feed digestibility & $65 \%$ \\
$\mathrm{CH}_{4}$ conversion factor & $6 \%$ \\
Milk production & $20 \mathrm{~kg} / \mathrm{day}$ \\
Milk fat content & $4 \%$ \\
Mature weight & $600 \mathrm{~kg}$ \\
Daily average weight gain & 0 (mature animals) \\
Percent of females that give & $80 \%$ \\
birth in a year & $8 \%$ \\
Manure ash content & $0.24 \mathrm{~m}^{3} / \mathrm{kg}_{\mathrm{Vs}}$ \\
Manure CH $\mathrm{CH}_{4}$ producing & capacity
\end{tabular}

Each cow daily ingests a gross energy of 197.52 MJ and produces $3.45 \mathrm{~kg}$ of volatile solids. The manure, liquid-managed and placed in an anaerobic lagoon (baseline reference configuration), releases a methane amount corresponding to 205.04 ton $_{\text {equiv, } \mathrm{CO}_{2}}$ per year (195.28 $\mathrm{kg}_{\mathrm{CH}_{4}} /$ year). $\mathrm{NO}_{2}$ emissions from manure are 4.87 ton $_{\text {equiv, } \mathrm{CO}_{2}} /$ year in such configuration.

Considering a CDM project that replaces the anaerobic lagoon by a biodigester (CDM-project configuration), manure $\mathrm{CH}_{4}$ emissions are reduced to 11.38 ton $_{\text {equiv, } \mathrm{CO}_{2}} /$ year $\left(10.84 \quad \mathrm{~kg}_{\mathrm{CH}_{4}} /\right.$ year $) . \quad \mathrm{NO}_{2}$ emissions in this configuration can be neglected.
Biogas composition is assumed to be $65 \%$ of $\mathrm{CH}_{4}$ and $35 \% \mathrm{CO}_{2}$, with a LHV of $23.10 \mathrm{MJ} / \mathrm{m}^{3}$ and a density of $1.2 \mathrm{~kg} / \mathrm{m}^{3}$. Daily production is about $50 \mathrm{~m}^{3}$ of biogas, which is available for flaring or to be used in energy conversion systems. According to Murphy et al. (2004), biogas combustion has an emission factor of $1.96 \mathrm{~kg}_{\text {equiv, } \mathrm{CO}_{2}} / \mathrm{m}^{3}$. Consequently, emissions due to biogas combustion are 35.77 ton $_{\text {equiv, } \mathrm{CO}_{2}} /$ year.

From the comparison of baseline and CDM project emissions summarised in Table 4, it can be noticed that the implementation of a biodigesterbased manure management system reduces GHG emissions from 209.91 to 47.15 ton $_{\text {equiv, } \mathrm{CO}_{2}}$ year (net reduction of 162.76 ton $_{\text {equiv, } \mathrm{CO}_{2}} /$ year). Considering that in the European market the CER (carbon credit) price is about $€ 10.00 /$ ton $_{\text {equiv, } \mathrm{CO}_{2}}$ (Econergy, 2006), this project would provide an annual income of $€ 1,627.60$ during project lifetime, estimated in 10 years. Considering an implementation according to Souza (2005), the farmer annual income would be $€ 162.76$ (10\% of the total). It must be pointed out that all this income may be considered profit from the farmer's point of view, since it can be considered there are no extra expenses connected to project implementation when compared to baseline the configuration.

\section{MILK CHILLING SCENARIOS ANALYSIS}

\section{New implementation scenario}

For this scenario, the analysis intended to verify which is the most suitable configuration for implementing a milk chilling system in a dairy farm that does not count on the equipment yet. The following configurations were considered:

1. a cooling tank with electric-driven vapour compression condensing unit and purchased electricity;

2. the same configuration of (1), with electricity provided by a generator driven by an Otto engine using biogas;

3 . the same configuration of (1), with electricity provided by a generator driven by a Diesel engine using a biogas/diesel mixture $(60 \% / 40 \%)$;

4. a cooling tank with a biogas direct-burning absorption chiller.

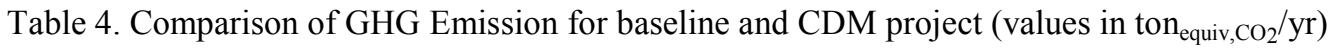

\begin{tabular}{cccc}
\hline GHG Emission Source & Baseline Scenario & CDM Project & Reduction \\
\hline $\mathrm{CH}_{4}$ from manure management & 205.04 & 11.38 & 193.66 \\
$\mathrm{NO}_{2}$ from manure management & 4.87 & 3.87 \\
$\mathrm{CO}_{2}$ from biogas combustion & & 35.77 & -35.77 \\
\hline Total & 209.91 & 47.15 & 162.76 \\
\hline
\end{tabular}

(") According to the IPCC guidelines, $\mathrm{NO}_{2}$ emissions for biodigesters can be neglected 
Table 5 presents the investment (IC), operational (OC), maintenance (MC) and total costs (TC) at present values (PV) for the considered configurations. Operational costs are due to electricity and diesel purchase costs. For this analysis, it is considered that the biogas is available to the farmer at no cost, since it results from the biodigester operation. Table 5 shows that configuration 2 is the best choice for this scenario.

\section{Purchased energy replacement scenario}

In this scenario, a farm that already has electricity-based chilling equipment (baseline configuration A) is considered. The goal is to verify if it is economically viable to replace the purchased electricity by local generation using the biogas provided by the CDM project (new configuration $\mathrm{B}$ ).

Table 6 compares costs for the above configurations considering present values and evaluates the lifecycle savings (LCS). It can be noticed that configuration $\mathrm{B}$ provides a small positive LCS, indicating that the replacement is economically viable. The payback for such a replacement is about 27 months.

It is important to point out that only the replacement of electricity required for milk chilling equipment is under consideration. If the generation of electricity for other farm requirements (lighting, heating systems, pumping systems, etc.) is to be considered, this implementation may become economically more attractive to the farmer, but further analyses are required.

\section{CONCLUSIONS}

The Brazilian dairy sector is characterised by a large number of producers, presenting low productiveness and product quality. Concerning quality, it is necessary to implement of cooling systems for milk conservation on the farm. Nevertheless, the main drawbacks to a wider use of those systems, besides the cultural aspects, are the access to financial resources and energy availability.

In this context, the goal of this work was a preliminary study to determine the best configuration of a milk chilling system for medium-sized dairy farms to be included in an anaerobic digestion manure management project based on the Clean Development Mechanism of the Kyoto Protocol, to be implemented by an investor interested in commercialising the generated carbon credits.

It was evaluated that the implementation of such a project for a 50-cow-dairy herd generates GHG emissions reduction of about $78 \%$ when compared to a manure management system based on an anaerobic lagoon, and produces $50 \mathrm{~m}^{3} /$ day of biogas that can be used for supplying farm energy requirements for heating and electricity generation.

The analysis showed that a biogas-fuelled Ottoengine electrical generator is an interesting alternative for electricity purchase replacement for an existing milk chilling system. For new systems, the best configuration is a cooling tank with electricdriven vapour compression condensing unit using the generated electricity.

If the electricity generation for other farm requirements (lighting, heating systems, pumping systems, etc.) is to be considered, as well as microcogeneration systems, these implementations may become economically more attractive to the farmer, but further analyses are required. It is also possible that absorption refrigeration systems become economically attractive in conjunction, which did not happen for the present scenario.

Table 5. Cost analysis for a new implementation scenario.

\begin{tabular}{ccccc}
\hline Configuration & IC & OC & MC & TC (PV) \\
\hline 1 & $18,000.00$ & $1,417.69$ & 900.00 & $33,039.24$ \\
2 & $21,160.00$ & - & $2,427.33$ & $32,667.87$ \\
3 & $22,150.00$ & $2,879.47$ & $2,905.83$ & $54,118.15$ \\
4 & $61,000.00$ & 403.69 & $3,050.00$ & $83,410.61$ \\
\hline
\end{tabular}

Table 6. Cost analysis for purchased energy replacement scenario.

\begin{tabular}{|c|c|c|c|c|}
\hline Configuration & IC & $\mathrm{OC}$ & $\mathrm{MC}$ & $\mathrm{TC}(\mathrm{PV})$ \\
\hline $\mathrm{A}$ & 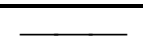 & $1,417.69$ & 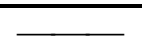 & $9,199.24$ \\
\hline B & $3,160.00$ & 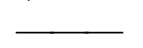 & $1,527.23$ & $9,054.69$ \\
\hline \multicolumn{4}{|c|}{$\mathrm{LCS}$} & 144.55 \\
\hline
\end{tabular}




\section{REFERENCES}

Nero, L.A. et al., 2005, Raw milk from four Brazilian milk-producing states: perspectives of compliance with the microbiological criteria established by the Instrução Normativa 51, Ciência e Tecnologia de Alimentos, Vol. 25, No. 1, pp. 191195. Available at: http://www.scielo.br/scielo.php?script=sci_arttext\&pi $\mathrm{d}=\mathrm{S} 0101-20612005000100031 \& \operatorname{lng}=\mathrm{en} \&$ nrm=iso\%3e.\%20ISSN\%200101-2061.\%20doi: $\% 2010.1590 / \mathrm{S} 0101-20612005000100031$.

Chan, G.L., 1985, Integrated Farming System. Elsevier Science.

Sant'anna, D. et al., 2003, Risk analysis of investments in-farm milk cooling tanks. Revista de Economia e Sociologia Rural, Vol. 41, No. 2, pp. 407-420 Available at: http://www.scielo.br/scielo.php?script=sci arttext\&pi $\mathrm{d}=\mathrm{S} 0103-20032003000200005 \& \operatorname{lng}=\mathrm{pt} \& \mathrm{nrm}=$ iso.

Bayer, M.M. et al., 2000, Computer-assisted engineering process and cost analysis for biogas valuation by cogeneration. In: Proceedings of Brazilian XIII Congress of Chemical Engineering, São Paulo, Brazil.

Jensen, J.K., Jensen, A.B., 2000, Biogas and natural gas fuel mixture for the future. In: Proceedings of $1^{\text {st }}$. World Conference and Exhibition on Biomass for Energy and Industry, Sevilla, Spain.

Walsh, J.L. et al., 1988, Handbook on biogas utilization. U.S Department of Energy, Alabama.

Massotti, Z., 2003, Biogas technical and economical viability in farms. Epagri, Brazil. Available http://www.cnpsa.embrapa.br/pnma/pdf doc/10Massotti.pdf.

Werner, U. et al., 1989, Biogas plants in animal husbandry. Deutsches Zentrum für Entwicklungstechnologien, Germany.

IPCC, 2007, Climate change 2007: the physical science basis - summary for policymakers, Intergovernmental Panel on Climate Change, Switzerland. Available at: http://ipcc-wg1. ucar.edu/wg1/docs/ WG1AR4_SPM Plenary Approved.pdf.

Liborio, I.T., 2005, Clean Development Mechanism Basis, Brazil. Available at: http://www.jusgentium.com/2005030702.pdf.

Brunacci, A., 2005, Brazil launches the first Latin-American carbon stock exchange, Brazilian Ministry of Development, Brazil. Available at: http://www.desenvolvimento.gov.br/sitio/ascom/notic ias/noticia.php?cd_noticia $=6651$.

Guimarães, S., 2005, Brazil has world leadership with 74 CDM-based projects. Valor Econômico, Brazil. Available at: http://infoener.iee.usp.br/infoener/hemeroteca/imagen s/90198.htm.

Lima, M. A. et al., 2006, First Brazilian inventory on GHG antropic emissions: cattle methane emissions. Brazilian Ministry of Science and Technology. Available at:

http://www.mct.gov.br/upd blob/ 8806.pdf.

Souza, J.C.V.B., 2005, Biodigester is indicated for carbon credit generation. Brazilian Agricultural Research Company. Available at: http://www.embrapa.br/noticias/banco de noticias/2 005/folder.2005-06-30.8880213159

/foldernoticia.2005-06-30.9185161360/ noticia.200507-07.6858175366/mostra noticia.

Diaz, G.O., 2006, Analysis of milk cooling systems in dairy farms using the biogas generated by CDM projects, M.Sc. Thesis, Universidade de São Paulo, São Paulo, Brazil. Available at: http://www.teses.usp.br/teses/disponiveis/3/3150/tde$\underline{15122006-095009 /}$

IPCC, 2006, IPCC Guidelines for national greenhouse gas inventories. Intergovernmental Panel on Climate Change, Switzerland. Available at: http://www.ipcc-nggip.iges.or.jp/public/gl/invs1.htm

Murphy, J.D. et al., 2004, Technical/ economic/environmental analysis of biogas utilisation, Applied Energy, Vol. 77, pp. 407-427.

Econergy, 2006, ECONERGY Carbon Market Newsletter 08/06. Available at:

http://www.econergy.com/Asp/DisplayPDF.Asp?NU $\mathrm{MBER}=250$. 